\title{
HISTORICAL DEVELOPMENT: THINKING HISTORY FOR THE 21st CENTURY
}

\author{
Ria Lusiandari ${ }^{1}$, Moses Glorino Rumambo Pandin ${ }^{2}$ \\ Faculty of Humanities, Universitas Airlangga \\ ria.lusiandari-2020@fib.unair.ac.id; moses.glorino@fib.unair.ac.id
}

\begin{abstract}
This article aims to examine the concept of historical thinking by looking at the development of historical learning from colonialism to reformation, as well as some examples of innovations in history learning through technology media. The development of history learning in Indonesia has a long story from the colonialism era to the reformation that changed from time to time. However, changes and reforms in the education system do not make students more interested in history. The 21 st century, known as the digital century, makes students' attention more focused on the present and the development of the times. Therefore, there are many innovations that are in line with technological media to support and maintain history learning in this era. The question from this research is how is history learning not favored by students when technological innovations to support this learning have developed? By using the literature review method and a qualitative approach, this article provides a new perspective through existing data. Because innovation cannot run effectively before it is accompanied by historical thinking, so the results of the research are historical thinking must be instilled from the start to support innovations that develop and attract students' interest. Based on the study, it is recommended that have historical thinking to further optimize technology develops innovation more effectively and ask for more interest in history.
\end{abstract}

Keywords: 21st Century, Historical Development, Paradigm

\section{INTRODUCTION}

In the current era of globalization, all fields are affected by progress. The 21 st century is known as the digital age, the world is rushing in all areas. The flow of globalization and modernization has reached all directions. Everything moves quickly, especially in the field of technology. Countries in the world compete to create new technologies to make people easier. Massive changes occur because technology is increasingly sophisticated. Every aspect of life is inseparable from technology, from small to large. In this case technology is very influential on the progress of life, but technology also has a negative impact.

In the world of education, technological developments are very influential in changing curricula, systems, goals, including the way of delivery. In Indonesia, education that was previously only accessible to the rich and was still very limited, now because of the movement of 
the times and technology, education can be obtained very easily. Science and knowledge are scattered due to increasingly sophisticated technology. Anyone and anytime is free to access all knowledge, no matter rich or poor and others.

Education is one important factor and also a need for humans because education is something that supports humans to develop. As stated in the 2003 National Education System Law, Chapter II Article 3, education aims: "National education has the function of developing and shaping the character and civilization of the nation which is useful in order to educate the life of the country, aiming at developing the potential of students to become human beings to have faith and devotion to God Almighty, have a noble character, are healthy, knowledgeable, capable, creative, independent and become democratic and responsible citizens (Law of the Republic of Indonesia Number 20 of 2003 concerning the National Education System) ". (1)

In formal schools, the way material is delivered is mostly influenced and inherited from the colonial period. However, after technology began to dominate all fields, learning in postreform schools as well as in this century has changed in such a way, changing with the flow in order to survive. Because in this era education is very important. From all these presentations, the main problem faced now is how to attract and raise motivation and enthusiasm in students or academics to keep wanting and having the will to learn in the midst of modernization and globalization today. And the learning that must be considered the most in this case is history learning. Because history learning is a lesson that greatly influences the character of the young generation by learning about past struggles and taking positive things for the future, this research is important to do.

Education regarding human quality in students in thinking, viewing, behaving using those inventions in the Fourth Technology Revolution era. Therefore, historical education is developed in a life full of changes with the aim of preparing students with ways of viewing, behaving, thinking, communicating, collaborating and other skills necessary to develop a future better quality of life. A historical event is something that is considered finished, non-recurring and is specific. Whereas present life is a continuation of past life and continues into future life with many repetitions of general matters (2). As a country that has a long journey from the past to the present day, it is necessary to renew the history of this century. As one of the important lessons, history learning should get more attention, especially on the way of teaching and learning. However, 
learning history in fact cannot easily attract interest, making boredom the reason cannot be fully justified. So what is lacking in studying history from ancient times to the present? This article will discuss the development of history learning from colonialism to reformation, the current problems of history learning, namely the weakened interest in history, the technology used as a solution and the concept of historical thinking as a solution. This article also aims to show the changes in history learning in several periods. Then, it also aims to analyze whether technology can attract the current generation to history or the concept of historical thinking can be one of the solution options in historical renewal in this digital age.

\section{METHOD}

This article used a descriptive research method, namely research by describing or explaining a research result. It used an approach whose results use narratives or descriptions instead of numbers or tables, namely a qualitative approach. Using the literature review method or literature review which is more inclined towards analyzing, assessing, critiquing the topics discussed in previous research. The data collection used in this article is by observing and documenting data from relevant and trusted journals and websites scattered on the internet (3).

The sources used in this article come from 20 journal articles and one website published between 2019-2021, some of which were also published under those years. All sources used in this article are trusted sources such as the Jurnal Pendidikan Sejarah, Historia, Indonesian Journal of History Education, Kanganga, Google Scholar, Lensa Budaya, Jurnal Pedagogia dan Dinamika Pendidikan dan koranbogor.com.

\section{RESULTS}

Part of the results in this study were obtained through literature reviews of 21 articles or journals and websites on the internet. The journal articles used as references in this article include published in 2021 with 2 journal articles (9.5\%), 2020 as many as 7 journal articles (33.3\%), in 2019 as many as 4 journal articles (19\%), 2018 as many as 4 journal articles (19\%), in 
2017 there were 2 journal articles (9.5\%), in 2014 there was 1 journal article (4.8\%) and in 2011 there were 1 journal article $(4.8 \%)$.

The sources and data totaling 21 are the results of studies conducted by previous researchers. These sources and references are taken because they are considered to have a suitable and relevant to the discussion that will be discussed in this article, which both research are the development of historical learning. Therefore, the data of 21 journal articles were collected using this literature review method which is used as a reference for conducting research. The sources obtained and used are either journal articles or articles on the website aiming to support the research of this article to make it more factual and accurate. Data on the development of historical learning from colonialism to the 21 st century are accompanied by technology to assist in the writing of this article.

\section{DISCUSSION}

During the Dutch colonial period, education was a limited thing. Education was a tool used for the economic interests of the Dutch East Indies government at that time. So that this limited education can only be accessed by the bumiputera elite.

In the curriculum that was applied at that time, there were still very visible limitations in learning history. As one of the important factors in the Dutch education curriculum, it should be assumed that history lessons improve the critical thinking skills of the native elite. Initially bumiputera students accepted Dutch colonialism, but this goal failed. (4)

History lessons in the colonial period must be taught in formal schools. This historical knowledge was needed for the job requirements of that time, from administrative staff to military matters. The history lesson here is the history of the Dutch homeland and tends to focus on the history of Europe, either classical history or medieval history.

History subject matter does not concern the greatness of the Indonesian nation in the past. This can be seen from the chronological arrangement and historical material taught in Dutch schools. Besides that, it was taught the history of the control of the Dutch colonial countries, such as the Dutch East Indies and the West Indies (4). In Brakel's (1914) study, history lessons in the 
Dutch education system were tools to support colonial government programs. Therefore, history subjects is different than than the history of the Dutch East Indies and it requires the mention of the Netherlands as 'homeland' as an essential part.

In the post-independence era or the old order era, history learning began to progress rapidly. The education system began to be oriented towards the objectives embedded in the 1945 Constitution, namely "Educating the Nation's Life" (fourth paragraph). Learning history at the time is one of the hopes that can reverse the situation so that people become democratic citizens. To achieve this goal, during this period the Indonesian history group was formed whose members were historians from Indonesia and also the Netherlands. Historical learning at this time has become a strategic tool for shaping, character and personality better. This decade of history learning tends to contain indoctrination to support political policy, where the material is mostly Soekarno's speeches, this is reinforced by law, in the Presidential Decree dated May 28 no. $145 / 1965$ explained that education is a tool to reject imperialism, colonialism, feudalism, capitalism.

Furthermore, the curriculum changed intending to form a human being with Pancasila in 1964. The education system in this era was known as the panca wardana system or the 5-aspect developmental system which focuses on moral, intellectual, emotional, skilful and physical development. The material taught also tends to be indoctrinated because it is taken from Soekarno's speech (5). In general, history learning during the Old Order era aims to instill the attitude and spirit of patriotism as well as to arouse a sense of nationalism to become a Pancasila human. History studies also contain not only speeches that intend to indoctrinate but also focus on the arts and the body.

During the New Order era, the education system changed and was even replaced four times. In 1968, historical studies contained anti-liberal democracy, anti-guided democracy, especially anti-Soekarno. Historical learning at this time was included in civic education as the legitimacy of Soeharto's power, even books circulating at this time had to side with Soeharto and SNI. In 1975, history learning entered Social Sciences and was merged with Earth Sciences. At this time, the authority tended to emphasize the human orientation of Pancasila, especially the moral of Pancasila. Through history learning, students are expected to be able to take exemplary figures and also focus on skill development and creativity. 
In 1984, history learning was divided into world history and national history. PSPB or Education of the History of National Struggle is a new subject and must be followed and legally validated. The PSPB material emphasizes the struggle of the Indonesian nation during the period of the proclamation of independence on August 17, 1945 until the era of the filling of independence which is divided into three classes, with the following teaching materials: a) class I: Regarding Dutch colonialism to the formation of the state ministry, b) class II: about The negotiation between Indonesia and the Netherlands to the PKI's unilateral actions that contradicted the values of the 1945 Constitution. c) Class III: around the unity of the Indonesian Student Action Unit (WE) to the National Development Plan as an effort to fill independence (5). In 1994, this period was abolished the History of National Struggle Education. Less study of history and social science, plus natural science and mathematics materials. During this period, history is used as a space for pride because its learning only focuses on world history and people's stories from the past to the present as well as material for fostering insight and national identity.

Entering the reform period, after the fall of Soeharto all systems underwent a major overhaul, including in education. In 2004, the movement of the times demanded that humans be more superior and competent because this old curriculum was changed to the KBK (CompetencyBased Curriculum). History books at this time were prohibited from distribution because they did not contain facts about the journey of the Indonesian nation. In 2006 the curriculum changed to KTSP (Education Unit Level Curriculum). This system gave history and social studies teachers the freedom to develop material according to their area so that history learning focuses on local history. In 2013 the KTSP system was changed to the 2013 curriculum (K-13) in this curriculum, history for high school is divided into compulsory history and specialization history, history learning is seen as a very important and honorable lesson to develop character so that the learning hours are increased.

The K-13 curriculum is a curriculum that is still in use today. The education system, which has always been renewed, even since the era of colonialism and experienced rapid development in the Old Order era until the reformation, has not actually been able to attract the younger generation to learn about history. The changes that occur in the education system are only limited to the demands of the times to move forward more. Technological developments are more attractive to the current generation to always update. Interest in history has decreased, accompanied by 
increasingly advanced technological developments. This is evidenced by the low and reduced levels of visits of the younger generation to meseum (6). In a survey conducted by Framesty, the theme of history that most students are interested in is the Early Civilization in the Indonesian Archipelago (7). In another research, the most effective way to attract students 'or learners' interest is history learning using documentary film media. Learning with the media of watching documentary films is said to make students or students interpret values and meanings nationalism (8).

The decreasing interest in history along with the movements of the times has made the government, teachers and those related to make reforms by adapting to the times, namely with technology. The young generation who are more interested in technology, especially smartphones, make history learning must also be packaged more attractively by utilizing existing technology and media. Many studies are carried out in different ways but both use technology, especially applications, to attract the adolescents.

Learning media can be said to be a learning aid, namely anything that can be used to stimulate thoughts, feelings, attention and abilities or skills of students so that they can encourage the learning process. In the use of additional applications, it can facilitate teaching and learning activities in order to simplify the process. The use of instructional media is usually understood to help the effectiveness of the teaching and learning process in the classroom (9). The function of learning media is media that is capable of displaying a series of events that actually occur in a long time and can be presented in a short time and an event that is described must be able to transfer the actual situation, so that it does not cause verbalism. The teaching and learning process can be successful if students interact with all the sensory organs. (10)

Hence, media are important for realizing effectiveness in learning. Media and methods are closely related, especially in history learning. The media here can become intermediary to attract and spark motivation to learn history. If the media work well to generate more interest and motivation, it will help balance the movements of modernization and globalization. With historical depictions that are more commonly known as boring and rote things, the media can change that point of view. To make this happen, it is necessary for teachers, teaching staff, historians and those who are experts in their fields to continue to be productive and to innovate to cover incorrect perspectives on history. 
Several studies show that historical learning have been combined with technological media as a form of adjustment to the world, especially the current digital age. Research conducted by Wibowo (11) turned out to be no more interesting than learning history with a lecture model than with technology based on E-Learning. This innovation is proven by research which is then applied to the XI IPS class students of SMA Negeri 9 Semarang. Another innovation uses smartphone media, where this learning does not focus on data and time but focuses on where the event took place. Digital maps were developed by Sari (12) at SMA Negeri 2 Surakarta with the use of smartphones, which almost every child has. Another innovation was researched by Rahmawati (13) who used audio media in her research to increase interest in history learning. Media using audio and images are combined, then examined again in the ECHA innovation by Susanti, et al. (14). ECHA here is an abbreviation of Elaboration, Cover Song, Historical Content and Audio Visual. Using the current trend, this media is based on Vlog which are clearly known to many people. Among students, his research shows that students can and are able to keep up with technology. By Susilo and Sofiarini (15) this research was conducted at SKTIP PGRI Lubuklinggu.

Other media used besides technology are local historical sites or heritage media. Research on direct media has existed and was carried out by Far-Far (16) who explained that interest and motivation arose from using the local historical system model. However, not all teachers or teaching experts can develop videos because of the cost and lack of technology.

The 21 st century as a digital age requires teachers or energy to hone more creative and try innovations in developing the character of their students. The role of teachers or history teaching staff is very influential in developing ways of thinking and surviving in the era of globalization (17). Teacher innovation is needed in learning history so that students not only memorize but also understand events, concepts and generalizations through empirical experience. History learning which includes many events must be structured, the teacher will not only tell all the events but also are required to teach effectively and structurally. The movement of this century requires not only teachers but also students to think more critically, analyze, think three dimensions of time and be able to find the values contained in historical material (18). Not only in an effective and structured manner, because conceptual teaching will also help students or learners, so that students are not 
only defending jar about the past but also relates it to the present especially for knowledge in the future (19).

It is clear that the use of media is not entirely effective in increasing interest in the study of history. The innovations made by historians, teachers and others have not been able to fully spark motivation in history. Historical learning coupled with technology as renewal and adjustment in this digital age still needs to be accompanied by historical thinking. Because of this, teachers, historians, teaching staff are very important in developing historical thinking in their students or students. Thinking with character and according to history will be able to make digital innovations more effective.

To be able to have historical thinking there are at least two models that underlie it. The first model is known as "The Five C's", namely Change Over Time, Causality, Context, Complexity and Contingency. These five components underlie historical thinking, where before students or students get this understanding, the teacher must first understand this concept. First, Change Over Time here means that history changes and lasts in time. Therefore history is called unique, because historical events will not repeat themselves. Second, Causality or Causality here means that the law of cause and effect is very applicable in history. The occurrence of a thing has a cause and the result of something must have a result. Third, context here means that history is always related, whether events between events, time between times or ages between ages. Because historical events are always interrelated. Fourth, Complexity here means that history is very complex and complicated to understand without boundaries. Because facts are spread out indefinitely, boundaries are needed. And finally fifth, Contingency or possibility here means that history is a science with possibility. In this component history becomes many possibilities and there are elements of the unexpected.

The second model is known as The Big Six which is a continuation of the first model. These six components consist of Historical Significance, Evidence, Continuity and Change, Cause and Consequence, Historical Perspectives, The Ethical Dimension (20).

1. Historical Significance or Historical Significance. 
In the past there were important and excluded things that were long term and short term. However, what is considered and is considered history is what is important and brings about change.

2. Evidence or Evidence. History only contains factual data. This fact is verydependent on data.

3. Continuity and Change or the Fixed and Changing. History is changing and permanent.

4. Cause and Consequence or Cause and Consequence. History is a science that is related to one another, both in the law of cause and effect or the other.

5. Historical Perspectives or Historical Perspectives, which means studying history with diachronic thoughts or historical thoughts and by using non-historical theories and approaches.

6. The Ethical Dimension or Ethical / Moral Dimensions. Historical events are sure to have both positive and negative impacts. Directly or indirectly, history with its truth must have benefits.

These historical basics will be very helpful for the development of history in the 21 st century. Especially in attracting interest and interest in the study of history. Through the concept of historical thinking, it is clear that history will be much more visible than just a story or memory. History learning should provide space for students to imagine and think creatively (21). Because history is not just story to story or event to event, but history is more than that. The 21 st century clearly gives more meaning to past events, because the purpose of learning history is basically to develop a way of thinking, character, and value that are ready for the future.

\section{CONCLUSION}

The 21 st century is a digital age, where all fields have been dominated by being completely digital. Changes in this era certainly greatly affect the movement of the world to become more sophisticated, including in the world of education. Education in this era is very important and a milestone for planning the future. The history of education in Indonesia has a long story since the era of colonialism. Education in colonialism era was very limited and not everyone can get it. After 
independence until the reformation of the education system, there are always changes in an effort to adapt to the changing times and the demands of the needs. Especially in history learning which is also continuously updated. However, in fact, this renewal does not guarantee that the learning of history is in demand by many people and can compete in the current modernization movement. Some of the factors causing this is that history has an image of being boring and rote learning. The emergence of a widespread image in society about this can be said to be a mistake in the previous education system which may have focused on lectures and memorization.

Therefore, innovations are needed to maintain historical learning. Teachers and experts in their fields try to attract interest through learning media with technology. However, this innovation cannot be effective if it is not accompanied by historical thinking. So it is very necessary to instill a way of thinking history such as "The Five C's", namely Change Over Time, Causality, Context, Complexity and Contingency. Then The Big Six, consisting of Historical Significance, Evidence, Continuity and Change, Cause and Consequence, Historical Perspectives, The Ethical Dimension.

\section{REFERENCES}

1. Anisa, Siti. Model Pembelajaran Talking Stick Dala Meningkatkan Keterampilan Mengkomunikasinkan Pembelajaran Sejarah bagi Peserta Didik. 2020.

2. Hasan SH. Pendidikan Sejarah untuk Kehidupan Abad Ke 21. Historia: Jurnal Pendidik dan Peneliti Sejarah. 2019 (April);2(2):61-72

3. Herlina, Nina. Metode Sejarah. 2020:1-39

4. Arifin, Faizal. Pembelajaran Sejarah pada Masa Kolonialisme Belanda. Pendidikan Sejarah. 2020 Juli 2;9(2):126-153

5. Batubara UN, Aman. Perkembangan Pembelajaran Sejarah Pasca KemerdekaanReformasi. Jurnal Pendidikan Sejarah. 2019 Januari 1;8(1):14-34

6. Hamdani Setyo Sejati. Menurunnya Minat Generasi Muda terhadap Sejarah [Internet]. 2019. [dikutip 5 Mei 2021]. Tersedia pada: http://koranbogor.com/lainnya/featured/menurunnya-minat-generasi-muda-terhadapsejarah-\%EF\%BB\%BF/

7. Framesty DA. Minat Peserta Didik terhadap Tema dan Materi Pembelajaran Sejarah. 2021:1-96

8. Prananda MN, Sarkandi, Ibrahim N. Efektivitas Sumber Pembelajaran Sejarah. Jurnal Pendidikan Sejarah. 2018 Juli;7(2):67-84 
9. Paramitha DO. Penggunaan Aplikasi dan Media dalam Efektivitas Pembelajaran Sejarah. Anotasi Bibliografi. 2021:1-3

10. Asnar dan Aksa. Peranan Media dalam Pembelajaran Sejarah Abad Ke-21. Pengembangan dan Penulisan Sejarah Kritis. 2017 Nov 16: 51-57

11. Wibowo HS. Efektivitas Pembelajaran Sejarah dengan Mengunakan Model Pembelajaran E - Learning. IJHE : Indonesian Journal Of History Education. 2014;3(1):6-10

12. Sari, Monica. Peta Digital : Inovasi Pembelajaran Produktif Abad 21 dengan Smartphone dalam Pembelajaran Sejarah. 2017:197-205

13. Rahmawati FN. Efektivitas Pemanfaatan Media Audio Visual Video Pembelajaran dalam Upaya Peningkatan Motivasi dan Hasil Belajar Siswa pada Pembelajaran Sejarah. 2011:125

14. Susanti ED, Sapto A, Gede Agung DA. Pengembangan Media ECHA (Elaboration, Cover Song, Historycal Content, Audio Visual) Berbasis Vlog dalam Pembelajaran Sejarah. Jurnal Pendidikan: Teori, Penelitian, dan Pengembangan. 2020 Maret;5(3):326-331

15. Susilo A, Sofiarini A. Pembelajaran Sejarah Online Mahasiswa Stkip PGRI Lubuklinggau di Masa Pandemik Covid 19. Jurnal Pendidikan Sejarah dan Riset Sosial Humaniora (KAGANGA). 2020 Juni;3(1):24-32

16. Far-Far, Gazali. Pengembangan Model Pembelajaran Sejarah Berbasis Situs Sejarah Lokal di SMA Negeri 5 Kota Ternate. Jurnal Pedagogika dan Dinamika Pendidikan. 2020 April 1; 8(1):109-117

17. Susilo A, Sarkowi. Peran Guru Sejarah Abad 21 Dalam Menghadapi Tantangan Arus Globalisasi. Historia: Jurnal Pendidik dan Peneliti Sejarah. 2018 Okt;2(1):43-50

18. Asri Z, Zafri, Hastuti. Penerapan Model Pembelajaran Berstruktur untuk Meningkatkan Efektivitas Pembelajaran Sejarah. 2018:1-26

19. Azhari AM. Pengembangan Pembelajaran Sejarah untuk Meningkatkan Minat Peserta Didik melalui Model Kontekstual. 2020 April 26: 1-8

20. Zed, Mestika. Tentang Konsep Berfikir Sejarah. Lensa Budaya. 2018;13(1):54-60

21. Supriatna, Nana. Pengembangan Kreativitas Imajinatif Abad Ke-21 dalam Pembelajaran Sejarah. Historia: Jurnal Pendidik dan Peneliti Sejarah. 2019 April;2(2):73-82 


\section{ATTACHMENT}

\begin{tabular}{|c|c|c|c|c|}
\hline No. & Category & Year & Amount & Percentage \\
\hline 1. & Journal Articles & 2011 & 1 & $4,8 \%$ \\
\hline 2. & Journal Articles & 2014 & 1 & $4,8 \%$ \\
\hline 3. & Journal Articles & 2017 & 2 & $9,5 \%$ \\
\hline 4. & Journal Articles & 2018 & 4 & $19 \%$ \\
\hline 5. & Journal Articles & 2019 & 3 & $14,2 \%$ \\
\hline 6. & Journal Articles & 2020 & 7 & $33,3 \%$ \\
\hline 7. & Journal Articles & 2021 & 2 & $9,5 \%$ \\
\hline 8. & Website & 2019 & 1 & $4,8 \%$ \\
\hline
\end{tabular}

